\title{
Selection of Language of Santriwati in Sallafiyah Al Fithrah Islamic Boarding School Semarang in Education Field: in Culture and Language Perspective
}

\author{
Suharyo, Redyanto Noor, Mirya Angraeni \\ (haryo.sastra@gmail.com) \\ Faculty of Humanities, Diponegoro University, Semarang \\ J1. Prof. Soedarto, Tembalang, Semarang, 50275, Indonesia
}

\begin{abstract}
This study aims to describe the selection of santri language in the field of education seen from a cultural perspective by taking a locus at the Al Fifthrah Islamic Boarding School in Semarang. The sample of this study were 30 female students who were randomly selected. Data is obtained through interviews, observations, and questionnaires. The results obtained are (1) Javanese language, in the variety of krama is still good $(60 \%-70 \%)$ and chosen and maintained as a communication tool in the educational field, (2) the respondents' ability in speaking Javanese language is relatively good (70\%) in understanding, communicating, and reading Javanese texts, (3) Javanese language, in the variety of krama is still relatively dominant as a means of communication, especially for Kiai, while for others (Ustadzah, friends, surrounding communities) Javanese uses a variety of krama, ngoko, and/or Bahasa; (4) the rank and position of the Javanese language (especially the variety of krama) has begun to be displaced by Bahasa, (5) the Kiai are still highly respected by the santri and ustadzah, (6) the santri(wati) are required to obey 17 rules of santri (7) The 17 rules of the santri's culture influence the order of thought, conduct, and speech, and (8) Javanese culture and Islamic culture also contribute to the choice of language/variety and ethics/culture in communication.
\end{abstract}

Keywords: selection, language, santri, the realm of education

\section{Introduction}

In a bilingual and/or multilingual society, the choice of language in social interaction is an inevitability. However, when someone chooses a particular language, he or she will be faced with a number of constraints and considerations. Constraints and considerations that they faced are not only a matter of language/variety but also cultural problems. In Javanese society, for example, there are language complexities and culture, because the things that need to be considered are the choice of languages (whether ngoko, krama, or krama inggil, or other languages/varieties), then, who is the interlocutor (age distance, social distance), and how the culture is. More so, (hypothetically), Javanese people who live in the Islamic boarding school environment. The reason is that things that must be considered besides language/variety are tradition/culture (Java) 
and Islamic boarding schools (Arabic-Javanese), such as the tradition of asking Kiai/caregivers, traditions reciting, and a tradition in the teaching-learning process.

To trace the hypothesis above, it is necessary to look at previous language selection, shift or retention studies. From the research findings of Regional Language Retention articles through Learning and Activities in Schools by Eko Widanto, it is said that defense and shift are two sides of a coin. Interrelated between the two. Language retention can be done through; (1) learning, (2) extracurricular activities, (3) communication tools on certain days. These are done to prevent the shift and extinction of languages, prepare speakers of regional languages in the future, and preserve national culture. Meanwhile, the results of Alamsyah's research, et al. show that speakers of Acehnese society are generally grouped into; (1) less able to speak Bahasa for fear of being wrong and (2) there is a group of people who can speak Bahasa but are very limited. The reason is that in practice, they often use mixed languages (Indonesia and Aceh). Therefore, there are situations of code-switching and code-mixing.

Sudirman Wilian shows that, empirically, based on scores (quantitatively) language choices in the family domain, neighborhood, kinship, it can be concluded that the Sasak language in Lombok will still survive even though there is the younger the age of the respondent then the higher the average choice of language. This is reasonable because that is the characteristic of a socialized society. That is still far from a symptom of a shift towards a monolingual Indonesian language society. Theoretically, according to him based on the experiences of other languages in the world that experience threats such as the language of Lampung in Indonesia (Gunarwan, 1994), these languages are threatened because they are no longer used by the younger generation at home with their families. Moreover, he classified the languages of the world into 3 types (languages that are extinct, endangered, and still safe). Of these 3 language groups, Sasak is classified as a safe language and even very safe. That is because; (1) demographically, Sasak still has a large number of speakers, (2) supported by language use in the home domain, (3) Sasak language still receives support from the government, and (4) is protected by law as a national cultural preserve.

Looking at the results of the research above, Javanese has the potential to be maintained by its speakers with a note that; (a) is still used in the home domain and (b) is still taught by parents of the next generation. In addition, in communities that are bilingual and/or multilingual, codeswitching and/or code-mixing will appear. Other terms of Javanese will exist if there is attention from the government and the field of education.

Then, the question is, how is the language selection of santri in the Sallafiah Al Fithrah Islamic boarding school in the educational field in a cultural and linguistic perspective? What language/variety (Javanese, Indonesian, English, Arabic) is chosen when speaking with the ustadzah/ustadz, kiai, or supervisors? At what time is this particular language/variety used? What norms (socio-culture) are used? Are there differences in norms (socio-cultural) that are significant when students talk to kiai compared to others (ustadzah, supervisor)? These questions will be answered through this research.

\section{Method}


This study took the location of Semarang Al Fithrah Islamic Boarding School as the object of study. The object of this study is all students in the boarding school. Meanwhile, the sample is determined randomly. Of the 60 students in the boarding school, 30 students were sampled in this study.

Data obtained by using interview techniques, observations, and questionnaires. Once collected, the data is analyzed by quantitative and qualitative methods.

\section{Results}

\subsection{Language Competence and Use in Communicating in Islamic Boarding Schools}

From the 30 respondents who were sampled in this study, the results were obtained: first, the competency of respondents in understanding Javanese speech fluently was $67 \%$, substandard $30 \%$, and not smooth 3\%. Second, respondents' communication competencies in using Javanese were obtained smoothly 67\%, 30\% substandard, and not smooth 3\%. Third, respondents' competence in reading Javanese texts (books, etc.) which are classified as smooth is $73 \%, 24 \%$ substandard, and 3\% not smooth. Fourth, the competence of respondents in writing Javanese was obtained as a result of $73 \%$ stating smooth, smooth $24 \%$, and not smooth $3 \%$.

In this study, it is also explored the competence of communicating in Javanese both in the form of ngoko and krama when speaking with kiai, ustadzah, board administrators, seniors, and friends. From the results of the data analysis, the results were obtained: first, santri, when communicating with kiai, using the Javanese language in a variety of $73 \%$, and the remaining $27 \%$ using other languages (Indonesian, Arabic). Second, when respondents communicate with teachers, those who use the Javanese language in the variety of krama is $30 \%$, Javanese in a variety of $n g o k o$ by $3 \%$, and the remaining $67 \%$ uses other languages (Indonesian, Arabic, English). Third, when communicating with senior or friends, respondents who used Javanese in a variety of krama were $43 \%$ using the Javanese language with a variety of ngoko by $33 \%$, and the remaining 24\% using other languages (Indonesian). Fourth, when communicating with fellow students who are of the same age, the results are obtained: using Javanese in a variety of krama of $17 \%$, using Javanese in a variety of ngoko by $70 \%$, and using other languages (Indonesian) by $13 \%$. Fifth, the language used by the respondents when communicating with the surrounding community was obtained: $10 \%$ used Javanese in a variety of ngoko, 53\% used Javanese in a variety of krama, and the remaining $37 \%$ used other languages. Sixth, the language used in the learning process/book reading was obtained: $7 \%$ used Javanese in a variety of ngoko, $43 \%$ used Javanese in a variety of krama, and the remaining 50\% used other languages (Indonesian, Arabic).

\subsection{Culture or Adab for Santri(wati)}

In this Al Fithrah Islamic Boarding School, there are rules or $a d a b$ which are intended for Santriwati as a guideline in social activities/life, such as: (1) knocking on the door and greeting before entering the room, (2) obeying the teacher's instructions (ustadz/kiai), (3) respect and honor the teacher, (4) say hello before mushofahah (kiss the kiai's hand), (5) do not cut the teacher's greeting (ustadz/kiai), (6) when passing by the kiai : a) when using a vehicle, if possible, go down 
or slow down the vehicle, b) when walking, should stop and be respectful, c) when sitting, if possible stand up, (7) head down when facing the teacher, (8) do not look at the teacher's face, (9) sit in guluk (kneeling) when the teacher in front of them, (10) comes to the recitation room before the teacher arrives, (11) Does not speak unnecessarily, (12) Uses covered and polite clothes, (13) does not use trousers when outside the room , (14) does not wearing tight clothes when reciting, (15) not carrying books in vain, books aligned with chests, (16) Not putting something on the book, (17) doing permission if there is a need.

\section{Discussion}

Considering the result of the analysis above, the result shows that santriwaties (especially those who live in Pondok Al Fithrah) have a decent ability in speaking Javanese (67\%-70\%). They $(67 \%)$ understand the Javanese utterances pretty well and can communicate fluently. This means that most of them have a passive ability (understanding) and productive ability (communicating) in Javanese. Besides, their ability to read Javanese is pretty decent too (73\%). Meanwhile, the rest of the santriwaties $(30 \%)$ admit that they can not do it well. After examing the correspondents who say that they are lacking in understanding Javanese, actually, they mean krama style. Thus, the correspondents' decent ability in Javanese (understanding and communicating) refers to their ability to use Javanese with karma style. So, in this case, the result is linear with the $73 \%$ percent which is showing that the respondent is using Javanese karma style when communicating with the kiai.

Then, what about the usage of Javanese when the santriwatis are communicating with the others (ustadzah, dorm supervisor, friends)? They usually (30\% s.d 45\%) apply Javanese karma style. The rest of the santriwaties (50\% s.d 70\%) use Javanese ngoko style or the other style (Bahasa Indonesia). It is understandable (percentage) because considering the status of the kiai is more respected than the others (ustadzah, dorm supervisor, and friends).

Another thing that can be remembered from the research result is that there is a tendency to use Bahasa Indonesia more often (15 s.d 50\%) in their activities, such as Al Qur'an reciting, communicating with ustadzah, friends and the society. It is safe to say that Bahasa Indonesia has started to threaten the existence of Javanese (especially karma style), especially in Pondok Pesantren Al Fithrah.

\section{Conclusion}

From the explanation above, there are several things to remember. First, Javanese is commonly used in Pondok PesantrenAl Fithrah as the main device to communicate, either krama or ngoko style. Second, the santriwaties' ability in mastering Javanese is relatively good (60\%$70 \%$ ), whether in understanding, applying or reading. Third, Bahasa Indonesia has started to become the top choice of santriwaties when communicating to ustadzah, friends or society. Fourth, there are different manners/norms when respondents communicate. When talking to their kiai, they tend to choose the Javanese karma style. Meanwhile, there is more language used and the style will be more various, such as Arabic/English. But, the usage of Arabic/English is an 
effect of code-mixing. Fifth, there is no different mannerism done by santriwaties in communicating with kiai/ustadzah, friends or even society. It is more like the quality of the manner of the speech is different, which means that when they are communicating with kiai, they will be more polite. Sixth, the percentage of santriwaties' chosen language is influenced by the obligations that make them need to be careful in speaking, doing something or interacting with kiai, dorm supervisor, ustadzah, friends and even society.

\section{References}

[1] E. Widanto, Pemertahanan Bahasa Daerah melalui Pembelajaran dan Kegiatan di Sekolah. Jurnal Kredo Vol.1, No.2, April, Kudus (2018)

[2] T. Alamsyah, R. Taib, Azwardi, M. Idham., Pemilihan Bahasa Indonesia sebagai Bahasa Pertama Anak dalam Keluarga Masyarakat Aceh Penutur Bahasa Aceh di Naggroe Aceh Darussalam. Jurnal Pendidikan Bahasa Melayu (Malay Language Journal Education) (MyLEJ). Nanggroe Aceh Darussalam (2011)

[3] S. Wilianm Pemertahanan Bahasa dan Kestabilan Kedwibahasaan pada Penutur Bahasa Sasak di Lombok. Linguistik Indonesia, Vol.1, tahun ke-28, Februari (2010) 